\title{
Historical evolution of the Abalario lagoon complexes (Doñana Natural Park, SW Spain)
}

\author{
Arturo Sousa Martín and Pablo García Murillo \\ Departamento de Biología Vegetal y Ecología. Universidad de Sevilla. Apdo. 874. 41080 Sevilla.
}

\begin{abstract}
This work aims to demostrate which factors have determined surface drainage and distribution of the present-day hygrophytic vegetation of Abalario, in Doñana Natural Park (Huelva). The area is difficult to interpret because its territorial framework is disfigured as a result of an intensive use of its natural resources having been superimposed in the normal territorial dynamics. The area occupied by lagoons has been reduced by more than $30 \%$ in less than 40 years. This percentage is almost $90 \%$ in the case of peat-bogs. Two large lagoons of which historical records exist have completely disappeared namely, Laguna de La Mediana ("the Median Lagoon") and Laguna de Invierno ("the Winter Lagoon"). A subsidiary aim is to establish the usefulness of the methodology used, i.e. field work carried out in parallel with historical documentation using cartography and records of past land use. This combination of approaches provides a key to interpret actual surface hydrology and vegetation.
\end{abstract}

Key words: Landscape, ecological history, Doñana, lagoons, peat-bogs, SW Spain.

\section{RESUMEN}

Este trabajo pretende mostrar los factores que han determinado el drenaje superficie y la distribución de la vegetación higrófita actual en Abalario, en el Parque Natural de Doñana (Huelva). El área es difícil de interpretar debido a que su marco territorial está desfigurado como resultado de un uso intensivo de sus recursos naturales que han sido superpuestos a la dinámica territorial normal. El área ocupada por las lagunas se ha reducido en más de un 30\% ( y casi el $90 \%$ en el caso de las turberas) en menos de 40 años. Dos grandes lagunas mencionadas en los registros históricos han desaparecido: Laguna de La Mediana y Laguna de Invierno. Al mismo tiempo, el trabajo intenta establecer la utilidad de la metodología utilizada: trabajo de campo realizado simultáneamente con un estudio documental (cartografía histórica, registros sobre los usos del suelo). Esto proporciona la clave para interpretar la hidrología superficial y la vegetación.

Palabras clave: Paisaje, ecología histórica, Doñana, lagunas, turberas.

\section{INTRODUCTION}

The recognition and study of changes in the landscape, entailing the study of the history of ecosystems, is an enormously interesting area of knowledge, not only in itself, but also for the information gained on the relationships between the different elements of natural systems.

González Bernáldez (1992) set the scale of historical changes taking place in wetland complexes. He indicated wetlands are arguably the most impacted ecosystems, and estimated that approximately $75 \%$ of European wetland ecosystems have already been destroyed.

It is important to perfect a methodology for this type of study, involving historical tracking of changes experienced by natural systems, that could also be extrapolated to other ecosystems of similar nature.

The interest in the topic has increased because wetland systems, are very sensitive to large-scale changes, and may act as an indicator ecosystem

Limnetica 16: 85-98 (1999)

(C) Asociación Española de Limnología, Madrid. Spain. ISSN: 2013-8409. 


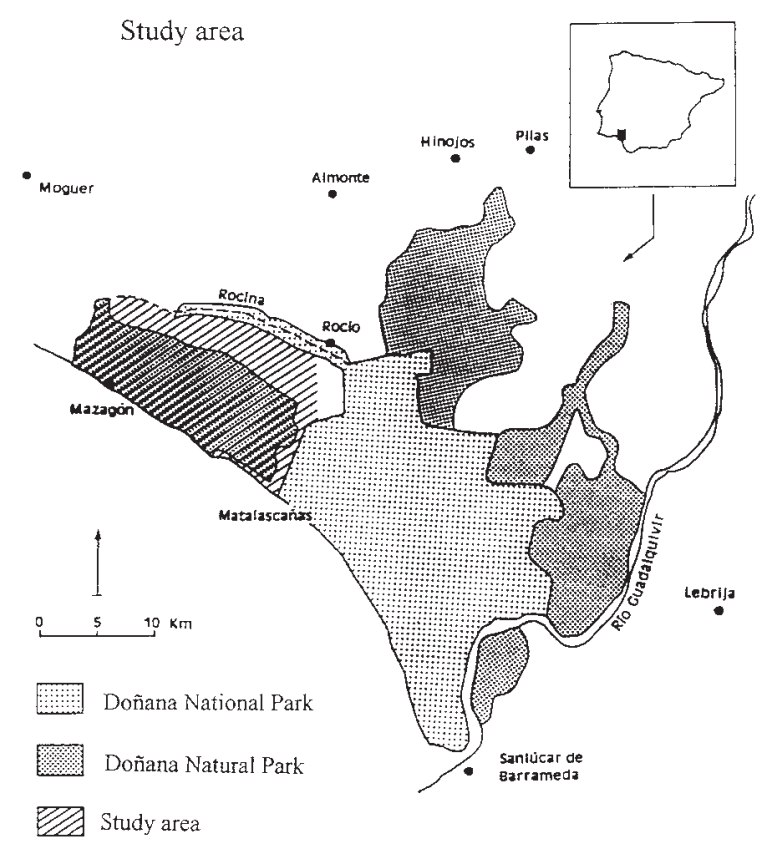

Figure 1. Study area. Área de estudio.

for human perturbations. In our case, we will see that it indeed necessary to consider global climatic changes in a complete explanation of regional changes and processes.

The study zone (Fig. 1) is situated on the coastal arc of Huelva, between deltas of Rivers Guadalquivir and Tinto. More precisely, it is the area between the Costa de Castilla and Rocina stream, bounded east and west by the C-445 road and the "Montes Propios" of Moguer, respectively (Fig. 2). These boundaries are shared with those of the western sector of Doñana Natural Park, although other land not belonging to the Park is also included. The approximate area under study is 25,000 hectares.

Substrate is dominated by Quaternary aeolian deposits, produced by a succession of dune fronts. In certain north-west areas, there is outcropping of Pliocene sands (Leyva \& Pastor, 1976). Climate is typically Mediterranean, although with a strong Atlantic influence, shown by milder temperatures and greater precipitations than inland (Allue, 1990).
Biogeographically, the study zone belongs to the Huelva Littoral Sector of the Gaditano-OnuboAlgarviense chorological province, included in the Mediterranean region (Rivas-Martinez, 1987). Bioclimatically, it is located in the upper thermomediterranean bioclimatic stage (Rivas-Martinez, 1987). It includes land belonging to the townships of Almonte, Bonares, Lucena del Puerto, Moguer, and Palos de la Frontera.

After the Spanish Civil War in the 1930s, traditional land uses, such as hunting, grazing, pasture land, and charcoal burning, all of which were compatible with conserving this highly-valued landscape, gave way to strong state intervention (Ojeda, 1987). The new dominant activity, was part of a national, autarchic, post-war economy, and concentrated on the urgent need to obtain raw materials (i.e. primarily wood pulp and essential oils) from rapidly-growing forestry crops. The territory was given over largely to plantations of eucalyptus, except in southernmost zones, where pines were planted instead.

The result of such a colonialist design was a radical alteration to the land. The land would no longer be considered as a useless desert (Ojeda, 1992), but a model region, a paradigm of forestry activity, with an exemplary production of raw materials. This ignored its subsequently recognized high environmental value, i.e. numerous lagoons, high spatial heterogeneity, high diversity of organisms and habitats, a wealth of different biological communities and rare species.

The gradual decline of forestry, due to the fall in production, inevitable in this type of crop, and the drop in value of raw materials, lead to abandonment of and depopulation (1953-68, according to Ojeda, 1987). The study zone today constitutes a phenosystem difficult to interpret disfigure and indecipherable, after decades of missmanagement.

Evidently, present-day communities and lagoon formations cannot be interpreted without closely studying the historical changes, which were deep and far-reaching, causing the original natural systems to conform to a set of physical and biotic elements which are fragmented and disconnected. Such information is a basis or refe- 


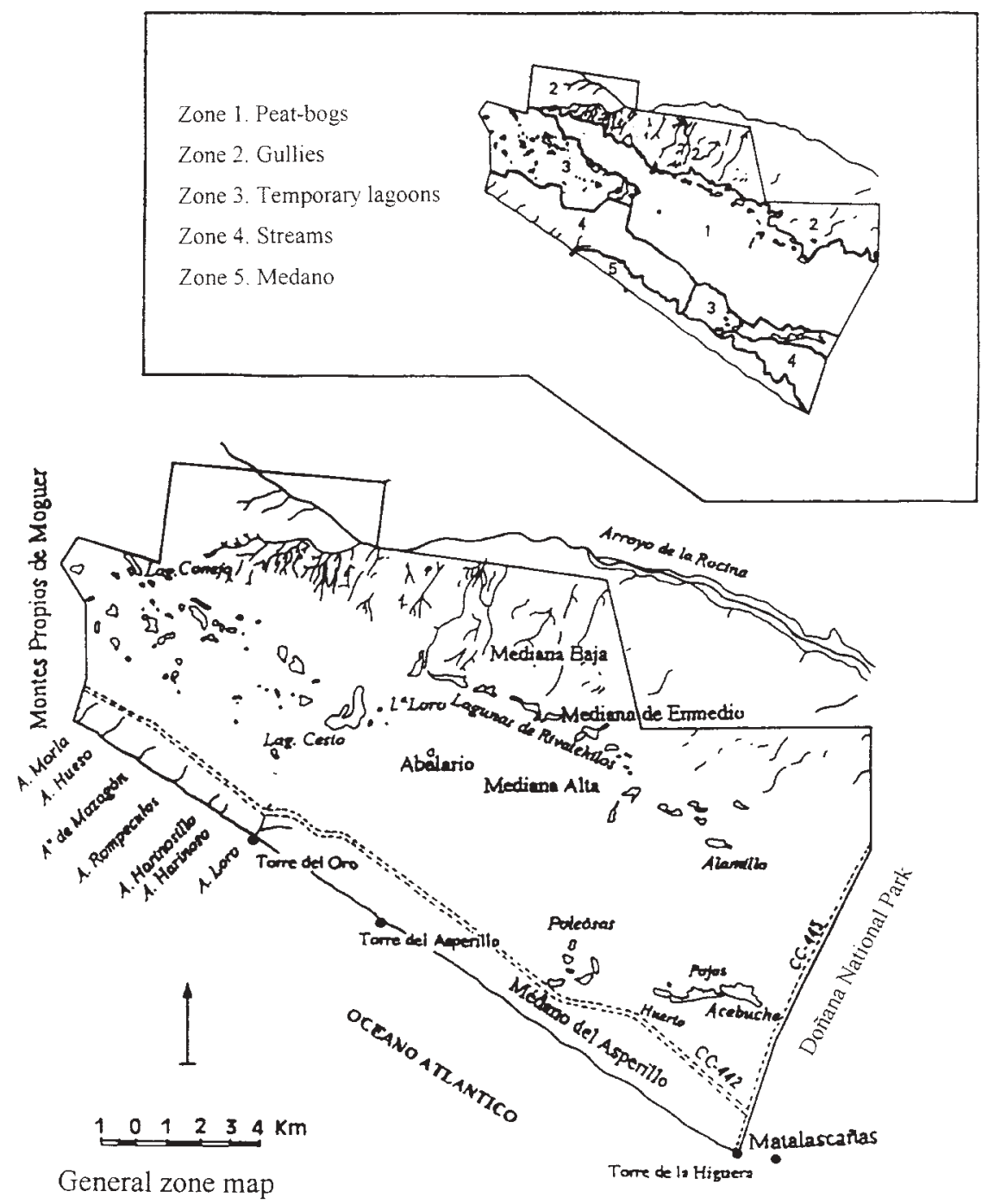

Figure 2. Present-day map of the study area, showing main localities, lagoons, streams, and other toponyms. Mapa de la zona. Mapa actual de la zona de estudio mostrando las principales localidades, lagunas, arroyos y otros topónimos.

rence tool for planning programmes (e.g. PORN, PRUG, restoration, public use) aimed at restoring this high-valued ecosystem to close to its original state.

The transformations that have taken place in the zone are a good example of the general transformation of the Atlantic littoral landscape linked to wetlands. However, the ecological nature of the elements involved in this system and the relationships between them show that this type of ecosystem is, or acts as if it is, especially sensitive to global climatic changes. Hence the interest in an approach that takes in these different viewpoints.

The paper deals with the changes produced in the study zone in the last two centuries. It considers changes to hygrophytic vegetation, to streams and brooks, and the transformations ex- 
perienced by lagoon formations, separately studying both existing types (i.e. seasonal lagoons and peat-bog). Finally, we look at the disappearance of two large lagoons whose existence is documented historically in archives and map libraries.

\section{MATERIAL AND METHOD}

The method used consisted in the cartographic reconstruction (scales 1:25000 and 1:50 000) of changes in both vegetation and surface draining sources of data were field observation laboratory data and archives. Surface measurements were obtained with a planimeter (PLANIX 5000). Resulting error is small given the low relief of the area (with slopes not exceeding $3 \%$ ).

Resulting maps were analyzed in the laboratory using aerial photographs (i.e. flights made in 1946 -scale 1:40 000-, 1956 -scale 1:33 000-, 1987 -scale 1:20 000-) and satellite images [Lansat-TM (1986 and 1990) and Spot (1989)].

Historical information, gathered from archives and map libraries, has allowed to track the rapid changes in land use and resource exploitation which have occurred in the area.

An acceptably reliable reconstruction of changes experienced in the study zone during the last two centuries helped identify the initial landscape disfigurement. The basis has been established for a model of the origin and functioning of surface drainage and vegetational dynamics across the landscape.

The regional toponymy, its variation and possible origins, have been analyzed historically from maps supplying data from the beginning of the $17^{\text {th }}$ century to date.

\section{RESULTS}

\section{Changes in the hygrophytic vegetation}

Floristically, the study zone is characterized (Garcia Murillo et al., 1995; Garcia Murillo \&
Sousa, 1997) by the large number of taxa with Atlantic distribution (i.e. Sphagnum inundatum, Theliptheris palustris, Osmunda regalis, Erica ciliaris, Pinguicola lusitanica, Potamogeton polygonifolius, Molinia caerulea) and the frequent occurrence of endemisms (i.e. Arenaria algarviensis, Daucus arcanus, Linaria tursica, Vulpia fontquerana). Woody plants are grouped into ten units (Garcia Murillo \& Sousa, 1997), each including various phytosociological associations. Following the criteria of Rivas Martínez (1987), these units can be divided into three series of plants. The first are the edaphophilous series of junipers, the second are the riparious oligotrophic woodlands, and the third, the climatophilous series of thermomediterranean coastal cork-oaks.

Garcia Murillo \& Sousa (1997) studied last forty years vegetational changes describing...

a) The decrease, or near loss, of vegetation associated to small streams and gullies. This vegetation is very rich in lianas and creepers (Lonicero hispanicae-Rubetum ulmifolii, Gully Unit).

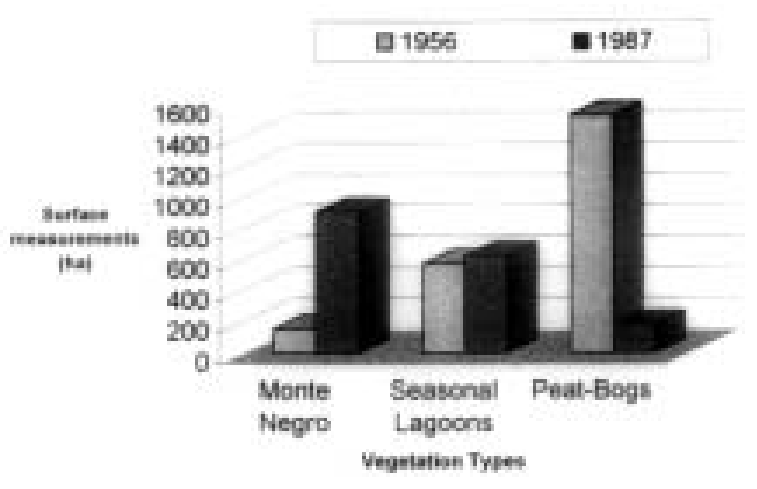

Figure 3. Changes in the hygrophytic vegetation. The decrease and near-disappearance of peat-bogs parallels an increase in hygrophytic shrub of Monte Negro. The area of lagoons has decreased 38.26 $\%$ (1301 ha) since 1956, with peat-bogs undergoing the greatest reduction. Cambios de la vegetación higrófita. Se puede ver que la disminución y la casi desaparición de las turberas es paralela al incremento del matorral higrofílico de Monte Negro. El área de las lagunas ha disminuido $38.26 \%$ (1301 ha) desde 1956, siendo las turberas las de mayor reducción. 
b) The reduction in area occupied by plant communities associated to peaty environments (Erico ciliaris-Ulicetum (minoris) lusitanicus, Peat-bog Unit). These areas were extensive in the fifties. Today, they are restricted to the Línea de Rivatehilos (Rivatehilos Line).

c) The increase in area occupied by hygrophytic shrubs (Erico scopariae-Ulicetum australis, Abalario Unit). This is a consequence of the degradation of peat formations. Hygrophytic plants have been able to take because they are less demanding with regard to flooding and availability of organic matter.

Figure 3 shows the changes in the hygrophytic vegetation of the zone during the period 1956-1987.

\section{Changes in the streams and brooks}

The study of the streams and brooks reveals considerable changes (Fig. 4). In 1987 (and today). The length of the few streams opening into the Atlantic has almost halved since 1956 . Today these streams hardly reach the road joining Mazagón with Matalascañas (Fig. 4). Torre de la Higuera stream, for instance, has totally disappeared.

The Mazagón streams, on the other hand, has been reduced in main length. The grater loss is for Loro stream, particularly when total length is considered to include tributaries (Fig. 4). Overall, reductions are of more than $60 \%$ in original length.

Today, the area around Médano del Asperillo has drainage, either endorheic nor exorheic. However, there are traces of ancient runoff lines in the area between the southern edge of the peatbogs and the Asperillo dunes.

Changes in gullies and brooks opening into the Rocina stream; northernmost in the study area, are less marked. There is, though, a decrease in the number and ramifications of gullies or seasonal streams. Planimetric measurements show, however, that this reduction was of only $30 \%$ during the period 1956-1987. Topping and felling of, especially, Eucalyptus globulus has dismantled this complex system of streams. The idea behind this ma-

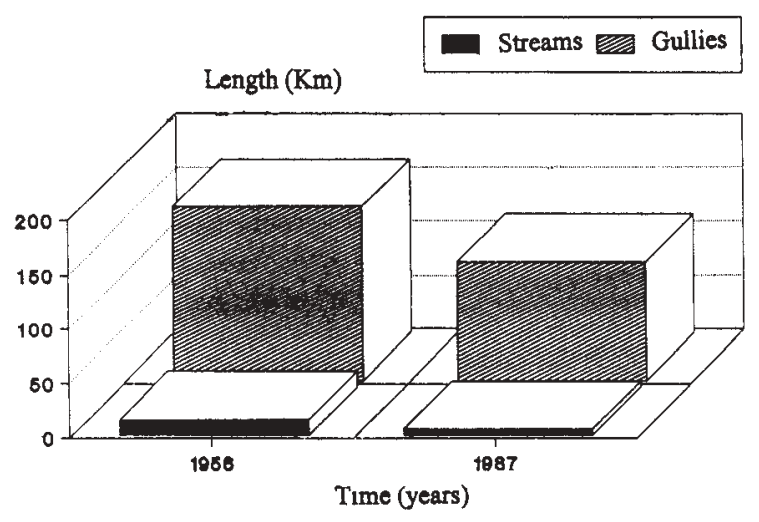

Changes in the streams (1956-1987)
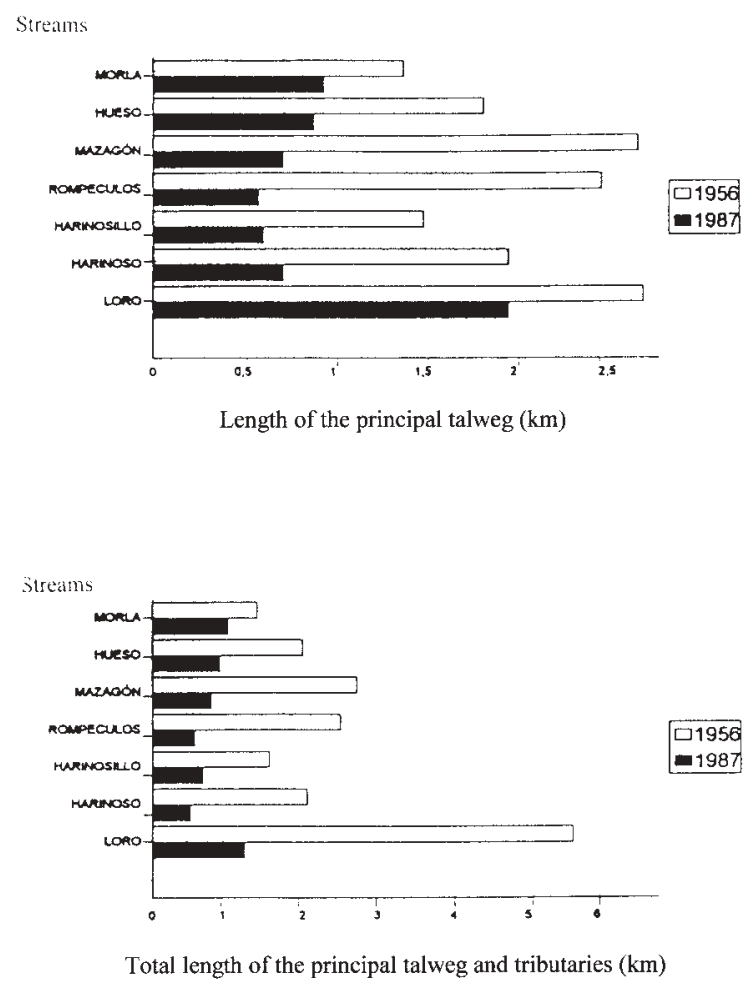

Figure 4. Decrease in length of each stream and brook in the study area (1956-1987). The overall decrease exceeded $60 \%$ for streams, and $30 \%$ for brooks and gullies. Cambios en arroyos y algaidas. Disminución en la longitud de cada arroyo y algaida en la zona de estudio (1956-1987). La reducción promedio excede el 60\% para los arroyos y el $30 \%$ para las cañadas y algaidas. 
nagement is that the system will reorganize in a subparallel network, similar to its previous state.

With regard to the situation of streams before the spanish Civil War, historical maps are available of areas to the coast (Gussefeld, 1781; Saavedra, 1810; Coello, 1869; Montojo y Salcedo, 1875; Valverde, 1880; Gonzalo Y Tarin, 1887; Carrasco, 1892; Noriega \& Cobo del Guzmán, 1897; Anon., 19 ${ }^{\text {th }}$ century; $19^{\text {th }}$ century naval maps; Ibáñez de Ibero, 1902). Topographic and geological maps drawn in the first half of the $20^{\text {th }}$ century are also available (San Miguel, 1913; Gavala, 1936; Mapa Topográfico Nacional, 1947; Mapa Topográfico Nacional, 1949; Mapa Topográfico Nacional, 1951).

The longest streams west of Médano del Loro (Loro Dune), Loro, Harinoso, Harinosillo, Rompeculos, Mazagón, Hueso, and Morla are undoubtedly the Mazagón and the Loro (Fig. 4). The latter could be the original drainage channel of the Winter Lagoon, as discussed below. In addition, there were other smaller ravines today extinct (i.e. the Atarazanas, Tojar del Lagarto, Carboneros streams, and the Higuera channel).

It would be excessively speculative to associate disappearance and regression of these streams solely to forestry activities over the last 50 years. In fact, it seems the decline of fluvial habitats began long before the XIX century. Regression became more marked during the nineteenth century, and experienced strongest impacts with forestry work starting in the 1940s.

Historical documents published by Mora Figueroa (1981), referring to the construction of watchtowers on the Huelva coast in the $18^{\text {th }}$ century, indicated that the greatest availability of surface waters was found in the Asperillo stretch, and that there was no water in the higher stretch and very little in the coastal stretch west of River Oro (sic) (Sousa \& Garcia Murillo, 1998).

\section{Changes in the peat-bogs}

The presence of communities of hairy heathers (Erico ciliaris-Ulicetum (minoris) lusitanicus) points to a peaty substrate originated by a process of pseudogleization requiring sluggish waters with abundant vegetation. Today, the area occupied by these peaty lagoons (the peat-bog unit of Garcia Murillo \& Sousa, 1997) extends over the zone known as "Rivatehilos" or "El Hilo" ("The String"). This unit or "string" (the local name for a series of aligned lagoons) divides the territory into two zones known as Mediana Baja (Low Median) and Mediana Alta (High Median). The two units have a different geomorphology, with high and low aeolic deposits respectively (Borja \& Diaz del Olmo, 1987). On the other hand, Mediana Baja is characterized by its Baja shrub and Mediana Alta by its Abalario shrub (Garcia Murillo \& Sousa, 1997). These data suggest a different geological origin to both areas.

The "reforestation" with eucalyptus, E. globulus in the high zones and E. camaldulensis in the more water-logged areas, after the Civil War lead to great evapotranspiration losses from mainly forests, and to a deepening of the water table. This was more marked with distance southwards from Rivatehilos. The extent of forestry practices impact on hydrology and ecosystems (Márquez, 1985; Ojeda, 1987; Espina \& Estévez, 1992, 1993), especially acute after the Civil War, is still not fully known. Vegetational changes indicate considerable reductions in water availability.

The impact of monoculture forestry lead, for example, to a decrease in the area flooded by lagoons and to the replacement of peat-bog vegetation [Erico ciliaris-Ulicetum (minoris) lusitani$c u s]$ by hygrophytic shrubs of "monte negro" (i.e. local name for communities of woody heath: Erico scopariae-Ulicetum australis). In addition to data obtained from analyse of aerial photographs, management-related alterations are unquestionably revealed by written documents (Gonzalo \& Tarín, 1887; Castro 1900a, 1900b, 1912; de la Lama, 1951; Kith Tassara, 1952; Espina \& Estevez 1992, 1993), oral testimony, from both natives of the zone (Espina \& Estévez, 1992), and from former managers (De La Lama, pers. comm.; Rodríguez Navarro, pers. comm.)

Peat bogs of the study zone show the clearest impacts caused by forestry. Some 40 years ago, the peat-bog vegetation extended over a much wider area, whose southern boundary coincided 


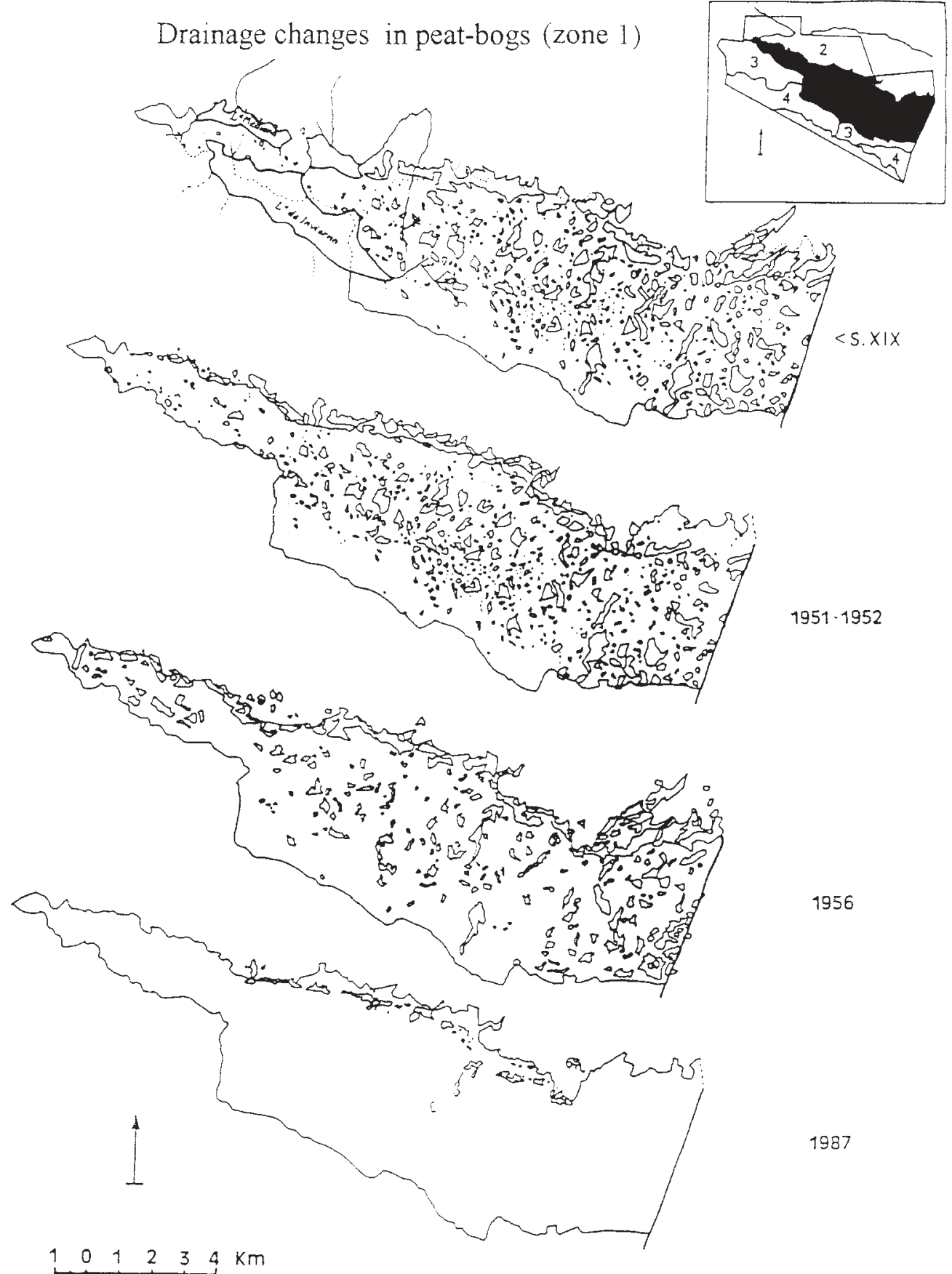

Figure 5. Gradual disappearance of the southernmost peat-bogs, before the $19^{\text {th }}$ century. The Winter and Median lagoons have disappeared, probably extinct by the end of the $19^{\text {th }}$ century. The map also shows the direction of disappearance of lagoons (i.e. from SW to NE). Cambios en las lagunas turbosas. Se muestra la progresiva desaparición de las lagunas turbosas más meridionales desde finales del s. XIX. Además destaca la desaparición completa de la laguna de Invierno y de la laguna Mediana, probablemente desde finales del s. XIX. 
approximately with the path joining the Poleosas lagoons with the village of Abalario. Indeed, past disttribution relicts are found in isolated "peaty points" (Erico ciliaris-Ulicetum (minoris) lusitanicus), far from Rivatehilos. The area of peatbogs has almost disappeared (Fig. 5), reduced today to 180 ha, scattered across about 30 isolated spots. This process can be assumed to have begun before the appearance of forestry. However, intensification of eucalyptus exploitation for essential oils and wood pulp, accelerated it. The result was a decrease of almost $90 \%$ in the area of peat-bogs between 1956 and 1987.

\section{Changes in the seasonal lagoons}

Lagoon complexes and peat-bogs differ in their drainage and filling cycle. Changes in lagoons are not as drastic as those in peat-bogs (Fig. 6).

No important changes are observed in the easternmost lagoons, except the artificializing of the Acebuche, La Pajas, and Huerto lagoons in the 80 s to make a reception area for visitors to Doñana National Park. This lagoon complex appears to be linked to, or is a continuation of, lagoons more to the east, which are within the confines of Doñana National Park.

It seems western lagoons formed part of a great ancient seasonal lagoon, mentioned in historical documents as the "Winter Lagoon".

Western seasonal and permanent lagoons have maintained their overall area in the period 19561987 (Fig. 3). However, it is probable that some have disappeared and been converted into "Monte $\mathrm{Ne}$ gro". On the other hand, new ones have appeared as a result of degradation of the ancient peat-bogs.

\section{The Median Lagoon}

The historical maps and texts suggest that the origin of the name "Mediana" is in the past existence of a great lagoon at the western edge of Abalario, the "Median Lagoon". The size of this lagoon (Madoz, 1848) would have amply exceeded any of the extant peat-bogs. This great lagoon, shown on various maps (Coello, 1869; Valverde, 1880; Carrasco, 1892; Ibáñez, 1902), gave rise to a string of lagoons, demonstrating an interphase or discontinuity.

The same maps allow reflection of the name "Mediana". This might indicate the size of the lagoon, since it would have been the largest of the peat-bogs, but smaller than the great "winter lagoon". Hence, the name "median" shows it as been intermediate size between the various marshy formations of the zone.

This territorial conformation fully coincides with property deeds of the 40s and 50s regarding sale, purchase, and valuation reports, as well as with the perception of landscape held by those involved in forestry work.

Originally thus, it seems there was a great seasonal lagoon (Winter Lagoon), another large, permanent lagoon (Median Lagoon), albeit slightly smaller than Winter Lagoon. These lagoons would have had different vegetation, associated to their different hydrology. Also, there would have been numerous very small lagoons, the Rivatehilos complex of peat-bogs. The group of peat-bogs characterized by the community Erico ciliaris-Ulicetum (lusitanicus) minoris and originated from this "median" lagoon to the whole most of which have now disappeared, lead to the extension of use of the name "Median" area. This toponym is present since at least the $19^{\text {th }}$ century.

Similarly, the name "Tojar Grande" ("Big Furze Shrub") on maps of 1945, 1981, and 1987, undoubtedly refers to a large area occupied by hygrophytic shrub (heather). This site approximately coincides with that of the extinct Median Lagoon (1880). It can therefore be speculated that the vanished great lagoon was replaced by hygrophytic vegetation (heather) and that, from the $1940 \mathrm{~s}$, the name "Tojar Grande" appeared in place of "Mediana". To distinguish topographically, zones are named "High Median" and "Low Median".

\section{The Winter Lagoon}

Archives and historical maps show the existence of a great ancient seasonal lagoon named the 


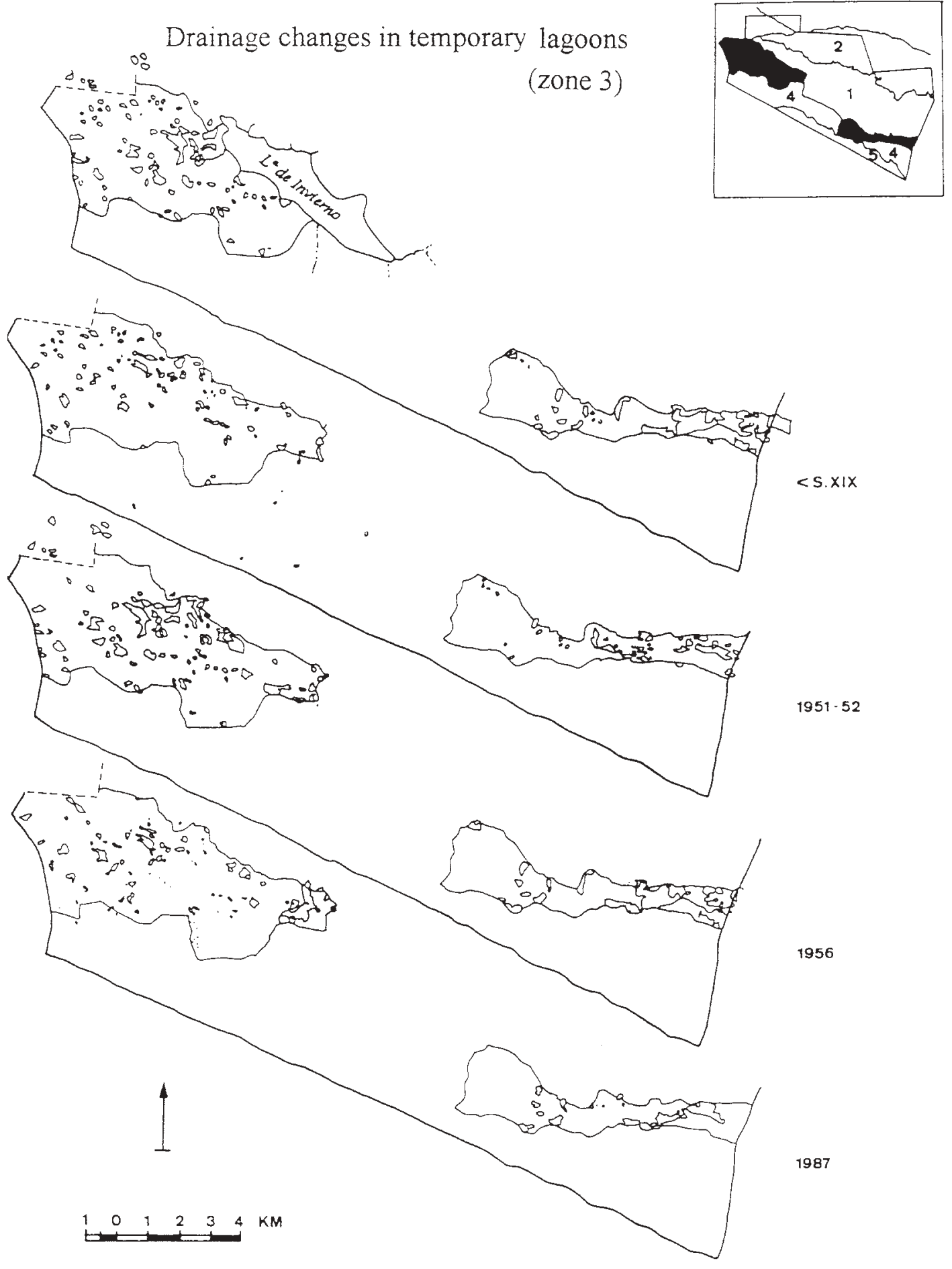

Figure 6. Changes in the seasonal lagoons. Cambios en las lagunas temporales. 
"Winter Lagoon". Madoz (1848), referring to the province of Huelva, states, "There are numerous lagoons in the province, the most important of which are the Winter Lagoon, situated to the north of Torre del Asperillo on the central part of the coast, the Median Lagoon, to the north of the Winter Lagoon and the Portil, south-west of Huelva ..." (translated from the original). The Loro stream, in that period known as River Oro (sic) $\left(16^{\text {th }}\right.$ century documents D1, D2, D3, D6, D12, D13, D14, and D15, cit. Mora Figueroa, 1981; maps of Gussefeld, 1781 and Saavedra, 1810; Gonzalo y Tarin, 1887:181), seem to have flowed into this lagoon.

The maps of Coello (1869), Valverde (1880), and Ibáñez de Ibero (1902), call this lagoon "Winter Lagoon", while Carrasco (1892), mentions the "Laguna de la Suerte" ("Lagoon of Destiny" or "Lagoon of Luck"). These works have enabled the reconstruction of historical changes affecting the area. On the other hand, it is possible this is the lagoon erroneously named by San Miguel (1913) as "Lagoon de Los Ansares" ("Goose Lagoon").

\section{DISCUSSION}

Analysis of available documents suggest the zone known as Rivatehilos, Línea de La Mediana, or Hilo de la Mediana by various authors does not correspond to the ancient line of flow connecting Abalario to La Madre de las Marismas without involvement of the Rocina stream.

The hypsometric conformation has stopped this "line" or "string" of the Mediana from forming a channel, by blocking with mobilized dunes. Neither of documents consulted, nor toponymy, gives any indication of the existence of such channel.

However, in exceptionally wet years (Espina \& Estévez, 1992), an increase in the area of the lagoon leads to contact between them, thereby setting up a line of flow towards La Madre de las Marismas.

Figure $7 \mathrm{a}$ sketches the geology of the area. Recent aeolian formations sit on a blue marl roof.
In addition, a channel through the blue marl roof exists, approximately where the primitive peatbog complex of Abalario stood. The division of waters more or less coincides with the edge of the channel (Fig. 7b).

North of this boundary, water tends to drain towards the Median or the Rivatehilos lagoons, while the southern zone tends to drain towards the Médano del Asperillo (Asperillo Dune). Channels through the blue marl roof have allowed to reconstruct the shape of the hypothetical basin on the left bank of the Rocina estuary. The area known today as Mediana Baja, with soil richer in basic materials than Mediana Alta could be an area of influence of the primitive estuary of the Rocina stream. This estuary would have carved by successive erosion the network of gullies and brooks, today almost vanished. Later, a more complex drainage area coinciding approximately with the primitive peat-bogs would have developed. A detailed map of runoff lines is shown in Figure 8a.

Figure $8 \mathrm{a}$ is a reconstruction of the line of flow of a hypothetical drainage involving the Rivatehilos lagoons. Topography clearly shows that runoff would be towards Rocina stream, and not towards a putative now vanished channel. [Source: Gonzalo y Tarin (1887), Espina \& Estévez (1992). Modified by the authors in accord with the M.T.N. and an aerial survey of 1956]. These observations, in our opinion rule out the hypothesis help by various authors stating that the Rivatehilos peat-bogs originate from the blocking of such channel.

Figure $8 \mathrm{~b}$ is a detailed reconstruction of the hypothetical situation of the Abalario peat-bogs, with special reference to the Median and the Winter Lagoons. It can be seen that a decrease in the water table would affect first the Winter Lagoon and then the southernmost peat-bogs, such as the Median Lagoon. This hypothesis is fully consistent with observations of changes in peaty vegetation, in toponymy, and with the reconstruction of lagoons from historical cartography.

The gradual disappearance of the southernmost peat-bogs from before the $19^{\text {th }}$ century indicates the drying up of hairy heather peat-bogs. 

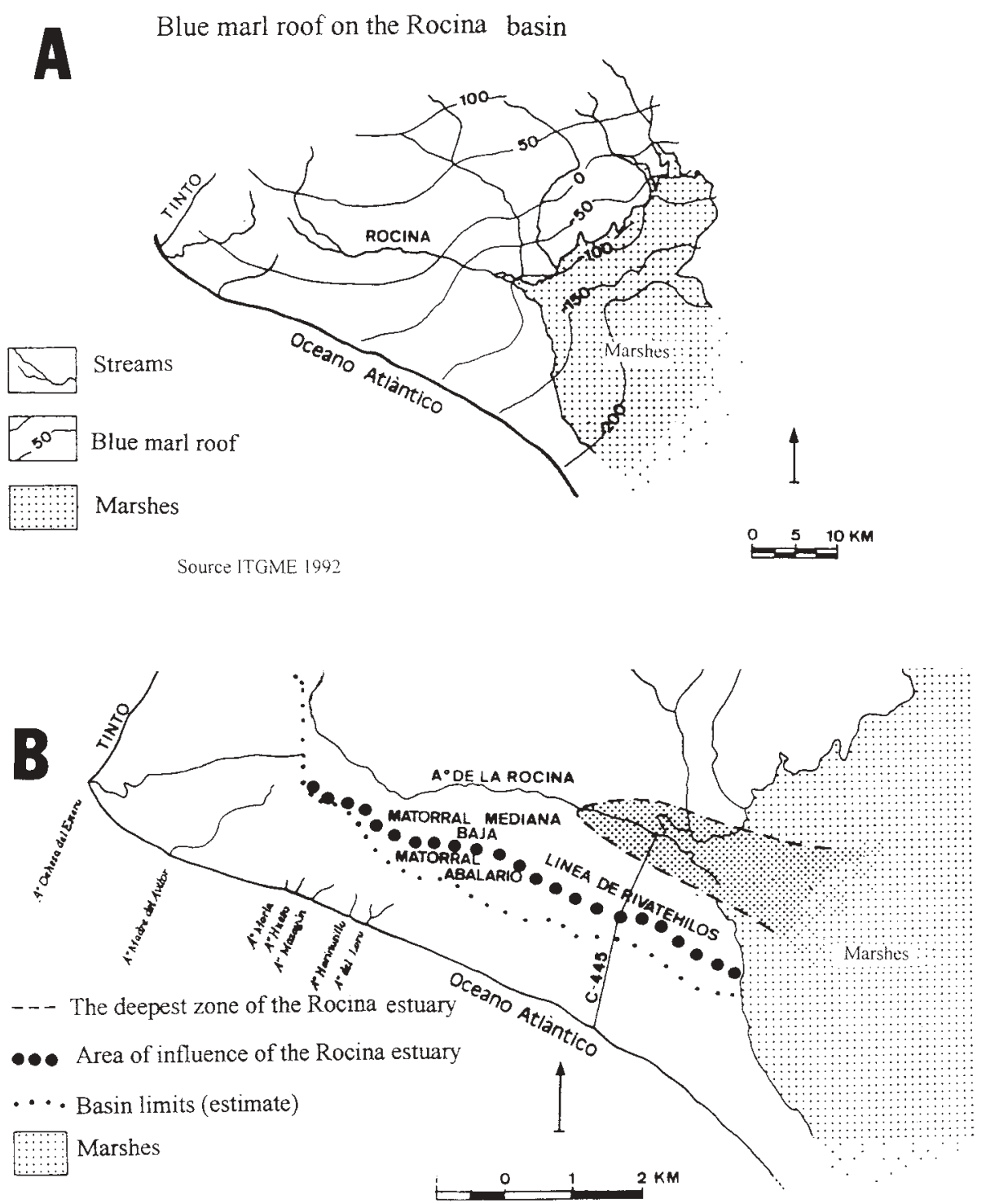

Figure 7. Geology, relief, and drainage of marshy formations. A) The channels in the blue marl roof in the study area suggest an hypothetical basin on the southern bank of the Rocina estuary. The area of influence reaches pastlocation of peat-bogs. B). Approximate coincidence of the northern edge of the channel in the blue marl roof with the division of waters. Source: geologycal data taken from the I.T.G.M.E. (1992); and own work. Geología, relieve y avenamientos de las formaciones palustres. A) Tomando en consideración las vaguadas en el techo de las margas azules, en el área de estudio, se reconstruye la hipotética cuenca de la margen meridional del estuario de la Rocina. Donde se aprecia que su área de influencia alcanzaba aproximadamente la disposición primitiva de las lagunas turbosas. B) En la segunda figura se puede apreciar la coincidencia de manera aproximada entre el límite septentrional de la vaguada en el techo de las margas azules, y la divisoria de aguas. Fuente: la geología está tomada del I.T.G.M.E. (1992), el resto es trabajo realizado por los autores.

Notably, the Winter and Median lagoons have completely disappeared, and were probably dry already by the end of the $19^{\text {th }}$ century. maps also show the apparent direction of disappearance of lagoons (i.e. from SW to NE) as a result of topography (Fig. 8a) and the line of runoff. Given the auto-ecological nature of the hygrophytic species involved (see Garcia Murillo \& Sousa, 1997), 

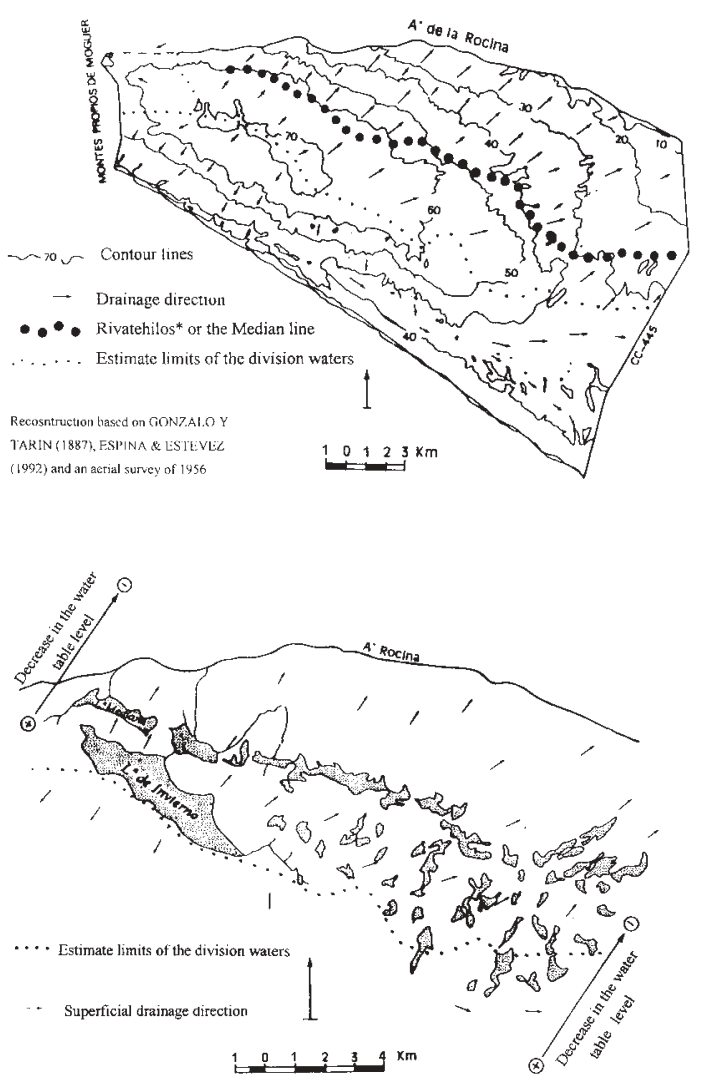

Figure 8. Disappearance of lagoon formations in the the general framework of drainage. A). Altitudinal map of the study area, with a reconstruction of the line of flow occupied by a hypothetical channel involving the Rivatehilos lagoons. Topography clearly shows that runoff would be towards the Rocina stream, and not towards the hypothetical channel. Source: Gonzalo y Tarin (1887), Espina \& Estévez (1992), modified by the authors from the M.T.N. and a 1956 aerial survey B). Decrease in the water table and effects on first the Winter Lagoon and then on southernmost peat-bogs (i.e. Median Lagoon). This hypothesis with changes detected in peaty vegetation, and with lagoon reconstruction consistent from historical cartography. La desaparición de formaciones lagunares en el marco general del avenamiento. A) Mapa hipsométrico de la zona de trabajo, con la reconstrucción de la línea de cauce que ocuparía un hipotético desagüe, del que las lagunas de Rivatehilos serían su testigo. Se aprecia claramente que la topografía obliga a que la escorrentía se organize hacia el Arroyo de la Rocina, y no en dirección al supuesto cauce desaparecido. Fuente: basado en Gonzalo y Tarín (1887), Espina \& Estevez (1992), y modificado por los autores en base al M.T.M. y a un vuelo de 1956. B) En la segunda figura se puede apreciar como la disminución del nivel freático afectaría en primer lugar a la laguna de Invierno y seguidamente a las turbosas meridionales (como la Laguna Mediana). Esta hipótesis coincide plenamente con los cambios detectados en la vegetación turbosa, y con la reconstrucción de la cartografía histórica de las lagunas. changes in drainage in the past few centuries, and taking into account topographical and geological conditions, these changes can only be explained as a result of the progression of a more arid climate. This coincides with the end of the period known as the Little Ice Age, between 1430 and 1850 (according to Pita, 1997).

In conclusion, we have shown the usefulness of the integrative methodology employed in this work i.e. the fruit of integrating floristics, vegetational studies, surface hydrology, historical cartography, aerial photographs and remote sensing, and archival research. Profound changes have been demonstrated, taking place in the study area over the past centuries. Among these changes identified, the disappearance of streams, peatbogs, and large lagoons are the most significative.

\section{ACKNOWLEDGEMENTS}

Work was partially supported by research project HID97-0321-C02-01 (DGICYT). We are grateful to the Director D. Javier Cobos and staff of Doñana Natural Park for assistance.

\section{BIBLIOGRAPHY}

ALLUE, J.L. 1990. Atlas Fitoclimático de España. Taxonomías. Ministerio de Agricultura, Pesca y Alimentación. I.N.I.A. Madrid.

BORJA, F. \& F. DÍAZ DEL OLMO. 1987. Complejos húmedos del Abalario (Entorno de Doñana, Huelva). Oxyura, 4 (1): 27-44.

DE CASTRO, A. F. 1900a. Repoblación de dunas.. Rev. de Montes, 559 (1-5): 225-232.

DE CASTRO, A. F. 1900b. Repoblación de dunas. Re.v de Montes, 561 (1-6): 281-285.

DE CASTRO, A. F. 1912. Dunas del Suroeste de la Península. Rev. de Montes, 843 (1-03): 151-159.

DE LA LAMA, G. 1951. Diez años de trabajos forestales. Rev.de Montes, 39: 195-201.

ESPINA, J. \& A. ESTÉVEZ. 1992. Programa de recuperación del Patrimonio del P.N.Doñana. Vol. III. Abalario. Informe inédito.

ESPINA, J. \& A. ESTÉVEZ. 1993. El espacio de repoblación de Cabezudos-Abalario. In: Intervenciones Públicas en el Litoral Atlántico andaluz. 
Efectos territoriales. Granados, M. \& J. F. Ojeda, (eds.): 95-107. Agencia de Medio Ambiente. Consejería de Cultura y Medio Ambiente. Sevilla.

GARCÍA MURILLO, P., A. SOUSA \& E. FUERTES. 1995. Sphagnum inundatum Russ., nuevo para Andalucía. Anales Jardín Botánico de Madrid, 53: 245.GARCÍA MURILLO, P. \& A. SOUSA. 1997. Vegetation changes in Abalario (Parque Natural Entorno de Doñana). Lagascalia, 19: 737-744.

GAVALA, J. 1936. Memoria explicativa del mapa geológico de España E. 1:50.000 y. Hoja N 1017 ("El Asperillo"). Inst. Geológico y Minero de España. Madrid.

GONZÁlEZ BERNÁlDEZ, F. 1992. Los Paisajes del Agua. Terminología popular de los Humedales. Ed. Reyero. Madrid.

GONZALO Y TARÍN, J. 1887. Mapa Geológico y Topográfico de la Provincia de Huelva E.1:400.00 y memoria. Inst. Geológico y Minero de España. Madrid.

I.T.G.M.E. 1992. Hidrogeología del Parque Nacional de Doñana y su Entorno. Inst. Tecnol. Geominero de España. Madrid.

KITH TASSARA, M. 1952. Diez años de colaboración de la $5^{\text {a }}$ División Hidrológica-Forestal con el Patrimonio Forestal del Estado. Rev. de Montes, 45: 166-172.

LEYVA, F \& F. PASTOR. 1976. Memoria explicativa del mapa geológico nacional Hoja 1017 (10-42; "El Abalario"). Memoria y mapa escala 1:50.000. Inst. Geológico y Minero de España. Madrid.

MADOZ, P. 1848. Diccionario Geográfico-estadísticohistórico de España y sus posesiones de Ultramar. Biblioteca Santa Ana (1990). Almendralejo.

MÁRQUEZ, D. 1985. Las repoblaciones de eucaliptos y su impacto en la última década 1973-1983. Revista de Estudios Andaluces, 5: 135-142.

MORA FIGUEROA, L. 1981. Torres de almenara de la costa de Huelva. Diputación Provincial de Huelva. Huelva.

OJEDA, J. F. 1987. Organización del territorio en Doñana y su Entorno próximo (Almonte). Siglos XVIII-XX.. I.C.O.N.A., Ministerio de Agricultura, Pesca y Alimentación. Madrid.

OJEDA, J. F. 1992. Políticas forestales y medio ambiente en Doñana y su Entorno. Agricultura $y$ Sociedad, 65: 303-357.

PITA, M. F. 1997. Los cambios climáticos. In: Climatología. J.M. Cuadrats \& M.F. Pita (eds.): 387-458. Ed. Cátedra. Madrid.

RIVAS MARTÍNEZ, S. 1987. Memoria del Mapa de Series de Vegetación de España E.1:400.000. I.C.O.N.A., Ministerio de Agricultura, Pesca y Alimentación. Madrid.
SAN MIGUEL, M. 1913. Las costas de la provincia de Huelva y sus variaciones en el periodo histórico. Bol. R. Soc. Hist. Nat., 13: 434-468.

SOUSA, A. \& P. GARCÍA MURILLO. 1998. Cambios históricos en el avenamiento superficial y la vegetación del Parque Natural del Entorno de Doñana (Sector Abalario, Huelva). Ería, 46: 165-182.

\section{CARTOGRAPHY}

1781. “Carte de Seville”. Autor: F. L. Gussefeld. Imp. Herederos de Homann. Escala 1:623.000. Escala gráfica en leguas de Alemania (7.409 m.), castellanas legales $(5.560 \mathrm{~m}$.) y de una hora de camino $(6.620$ m.), de 20 al grado (3 millas) y toscas (1'9 m).

1810. "Plano geográfico de Moguer, con los movimientos del General Lacy”, por D. Angel Saavedra, Ayudante Primero de E. M. Plano Geográfico de Moguer y sus inmediaciones, referentes a los movimientos de la División General Laci en Agosto de 1810 quando batió a las tropas del general ArambergoAtula? de León y Septiembre primero de 1810= Mampoey=(sic). Escala aprox. 1:150.000 (estimada). Escala gráfica en leguas. Sin proyección alguna. Perfiles abatidos. Cartoteca Histórica del Servicio Geográfico del Ejército.

1869. "Huelva" por D. Francisco Coello, Coronel de Ingenieros. Atlas de España y sus posesiones de ultramar. Para Diccionario geográfico-estadístico-Histórico. Notas estadísticas e históricas escritas por Pascual Madoz. 1869, Madrid. Escalas gráficas: Leguas legales, Millas marítimas, etc. Escala aprox. 1:200.000. Meridiano de origen de Madrid. Cartoteca Histórica del Servicio Geográfico del Ejército.

1875. "Costa Sudoeste de España”. Hoja II (desde Huelva hasta la Torre de la Higuera). Según trabajos realizados desde $1865-1870$ por la Comisión Hidrográfica a cargo de D. José Montojo y Salcedo. Dirección de Hidrografía, Madrid 1875. Carta naútica. Escala aprox. 1:50.000. Meridiano en el origen de San Fernando. Sin escala gráfica. Cartoteca Histórica del Servicio Geográfico del Ejército.

1880. "Provincia de Huelva", por D. Emilio Valverde, Comandante de Infantería. E.1:750.000. Atlas Geográfico descriptivo de la Península Ibérica, Islas Baleares, Canarias y Posesiones Españolas en Ultramar por el Comandante graduado 
Capitán de Infantería D. Emilio Valverde y Alvarez, auxiliar que ha sido del depósito de los Guerra, Provincia de Huelva (sic). Imprenta y fotografía de la Biblioteca Nacional. Cartoteca Histórica del Servicio Geográfico del Ejército. Sin escala gráfica ni proyección.

1892. "Nuevo mapa geográfico estadístico de la provincia de Huelva". Autor: José Carrasco Padilla (Ecxma. Diputación Provincial de Huelva). E. 1: 300.000. Meridiano de origen de Madrid. En "La representación del territorio, Huelva", Cartoteca del Instituto Geográfico Nacional.

1897-1900. "Provincia de Huelva, nivelación”, por el Instituto Geográfico Estadístico. Dibujado por F. Noriega y J. Cobo de Guzmán. Trabajos topográficos desde 1897 á 1900. Proyección Tissot. Altimetría deducida del mapa 1:100.000.

Sin escala gráfica, meridiano de origen de Madrid. Escala estimada 1:500.000. Cartoteca Histórica del Servicio Geográfico del Ejército.

S. XIX. "Provincia de Huelva", Anónimo. Sin proyección, ni escala. Escala estimada 1:200.000. Cartoteca Histórica del Servicio Geográfico del Ejército.

S. XIX. "Parte Sudoeste de la Provincia de Huelva", Cuerpo de E.M. S. XIX ó 1870/1878 Parte de la Provincia de Huelva, anónimo. Escala y proyección desconocida. Escala estimada 1: 100.000. Cartoteca Histórica del Servicio Geográfico del Ejército.

1902. "Mapa de España (Ibáñez de Ibero, 1902)”. Escala 1:500.000.

Mapa de España formado por el excmo. señor Mariscal de Campo D. Carlos Ibáñez é Ibáñez de Ibero con motivo de la división del territorio en zonas militares para situar las reservas y depósitos del ejército (sic). Publicado en 1884 y reproducido en 1902. Lit. Instituto Geográfico y Estadístico. Sin proyección, meridiano en el origen el de Madrid. Sin escala gráfica. Cartoteca del Instituto Geográfico Nacional

1947. "Mapa topográfico Nacional E. 1:50.000, Hoja 1000 ("Moguer")". 1 1a edición, 1947. Con cuadrícula de la Proyección de Lambert y meridiano en el origen de Madrid. Dirección General Instituto Geográfico y Catastral y Servicio Geográfico del Ejército. Escala gráfica en metros. Edición Militar. Ejemplar nº 0664. Cartoteca Histórica del Servicio Geográfico del Ejército.

1949. "Cartografía Militar de España E.1:25.000". Hoja 1017 ("El Picacho"), cuarto IV-III ("El Picacho"). Escala gráfica en metros. Meridiano en el origen de Madrid. Proyección de cuadrícula de Lambert. levantado en 1949. Servicio Geográfico del Ejército, 1952. Dpto. Biología Vegetal y Ecología, Univ. de Sevilla. Mapa topográfico Nacional

1949. "Cartografía Militar de España E.1:25.000". Hoja 1017 ("El Picacho"), Cuarto I ("El Abalario"). Mapa topográfico Nacional. Escala gráfica en metros. Meridiano en el origen de Madrid. Proyección de cuadrícula Lambert. Levantado en 1949. Servicio Geográfico del Ejército, 1952. Dpto. Biología Vegetal y Ecología, Univ. de Sevilla.

1951."Mapa topográfico Nacional E. 1:50.000", Hoja 1017 ("El Picacho"). Coordenadas geográficas con el meridiano en el origen de Madrid. Escala gráfica en metros. $1^{a}$ edición. Dirección General del Instituto Geográfico Catastral y Servicio Geográfico del Ejército. Cartoteca del Instituto Geográfico Nacional. 